IZA DP No. 7323

Offshoring and Productivity Revisited:

A Time-Series Analysis

Pablo Agnese

March 2013 


\title{
Offshoring and Productivity Revisited: A Time-Series Analysis
}

\author{
Pablo Agnese \\ FH Düsseldorf \\ and IZA
}

\author{
Discussion Paper No. 7323 \\ March 2013
}

\author{
IZA \\ P.O. Box 7240 \\ 53072 Bonn \\ Germany \\ Phone: +49-228-3894-0 \\ Fax: +49-228-3894-180 \\ E-mail: iza@iza.org
}

Any opinions expressed here are those of the author(s) and not those of IZA. Research published in this series may include views on policy, but the institute itself takes no institutional policy positions. The IZA research network is committed to the IZA Guiding Principles of Research Integrity.

The Institute for the Study of Labor (IZA) in Bonn is a local and virtual international research center and a place of communication between science, politics and business. IZA is an independent nonprofit organization supported by Deutsche Post Foundation. The center is associated with the University of Bonn and offers a stimulating research environment through its international network, workshops and conferences, data service, project support, research visits and doctoral program. IZA engages in (i) original and internationally competitive research in all fields of labor economics, (ii) development of policy concepts, and (iii) dissemination of research results and concepts to the interested public.

IZA Discussion Papers often represent preliminary work and are circulated to encourage discussion. Citation of such a paper should account for its provisional character. A revised version may be available directly from the author. 


\section{ABSTRACT}

\section{Offshoring and Productivity Revisited: A Time-Series Analysis*}

The subject of offshoring and productivity has not yet received the attention it deserves. Here I propose a simple framework for estimating the contribution of these strategies to the growth rate of labor productivity from a time-series perspective. This framework is then used to assess the impact of offshoring on skill upgrading and the labor share. For both empirical questions I take up the study of a group of Japanese industries during the recent years of slow growth. The results should be interpreted with caution yet clearly suggest that offshoring can improve labor productivity in the Semiconductors industry. Moreover, offshoring is found to be the source of important changes among industries with different skills (skill upgrading) and an important factor behind the fall of the labor share.

JEL Classification: J23, J24, E25

Keywords: $\quad$ offshoring, labor productivity, skill upgrading, labor share

Corresponding author:

Pablo Agnese

FH Düsseldorf

Department of Business Studies

Universitätsstraße, Gebäude 23.32

40225 Düsseldorf

Germany

E-mail: pablo.agnese@fh-duesseldorf.de 


\section{Introduction}

Much has been said about offshoring and its employment effects - which might seem at times to be quite ambiguous. Far less, however, has been said on the productivity effects. Here we will take up the up the study of offshoring and productivity using a time-series perspective for the industry, something on which the literature has not yet produced a clear consensus. To achieve this I will take a look at a major event in the Japanese economy: the 'lost decade' - that period of economic contraction which spans from somewhere in the 1990s to present days, and which is characterized by a slowdown of the growth rate of productivity. With this landscape in mind, our main objective will be to assess the impact of offshoring strategies on the performance of industries.

I will propose a simple model whereby it will be possible to derive the net effect of offshoring on the growth rate of labor productivity for different industries. This first empirical exercise will simulate the growth rate of labor productivity after the East Asian crisis (1997) assuming that the offshoring strategies remained unchanged at that initial level. Considering that over the last few years the offshoring of Japanese activities has really leaped forward (see Agnese, 2012), then it is of interest to see whether these activities may have prevented a more pronounced downturn of economic activity. ${ }^{1}$ A second empirical exercise will look upon offshoring as a source of skillbiased technological change, in the sense that these managerial strategies can lead to skill upgrading as well as to changes in the industry's labor share. Given that the labor share has been falling in most of the developed world, it will be useful to see how much offshoring has contributed to that change in Japan.

The Japan Industrial Productivity (JIP) Database (RIETI, 2011) will provide the data on a vast number of economic activities classified as 108 industries, out of which we will be using four for reasons that will become clear below. Our main results, which are in line with the recent literature, point to the existence of positive effects of offshoring on the growth rate of labor productivity for some of the industries (see Amiti and Wei, 2009, for the US, Girma and Görg, 2004, for the UK, and Hijzen et al., 2010, for Japan). Our second set of results suggests that offshoring can be seen as a source of skill-biased technological change because of, first, the presence of skill upgrading (e.g. high-skill workers see their wages increase due to higher productivity) and, second, the negative effect of offshoring on the labor share (e.g. firms resources from labor to more capital-intensive activities). ${ }^{2}$

\footnotetext{
${ }^{1}$ The recent Japanese experience is very well documented in several places and from different angles (see Caballero et al., 2008, Fukao and Kwon, 2006, Hayashi and Prescott, 2002, or Krugman, 1998, among many others).

${ }^{2}$ References on skill upgrading abound (see, among several others, Berman et al., 1994, and Feenstra and Hanson, 1996, for the US, Geishecker and Görg, 2005, for Germany, Head and Ries, 2002, for Japan, or Hijzen et al., 2005, for the UK). I am unaware, however, of any studies on the relationship between
} 
The industries I will be focusing on are classified by the JIP Database as information technology (IT) manufacturing industries. Table 1 condenses some comparative information on the broad sectors within the database for which data were available (1976-2008), and shows that IT-Manufacturing industries are traditionally more productive. Even when all sectors have been hardly hit by the slump, the IT-Manufacturing sector has still managed to fare reasonably well.

Table 1: Labor productivity growth rate, broad sector averages (\%).

\begin{tabular}{lccccc}
\hline \hline & $1976-2008$ & $1976-1980$ & $1981-1990$ & $1991-2000$ & $2001-2008$ \\
\cline { 2 - 6 } IT-Manufacturing & 5.81 & 8.14 & 9.51 & 3.40 & 2.73 \\
IT & 4.32 & 5.99 & 6.68 & 3.21 & 1.73 \\
Manufacturing & 3.53 & 6.24 & 6.86 & 2.19 & -0.63 \\
All & 2.80 & 3.68 & 4.69 & 2.78 & -0.09 \\
\hline
\end{tabular}

Source (all tables and figures): JIP Database (RIETI, 2011), own calculations.

Figure 1 complements the previous information and shows more in detail the downward trend of labor productivity for the same broad sectors. This general decline in the performance of the economy was severely felt especially after the 1997 crisis, when the growth rate of labor productivity stood at negative levels for many of the years that followed.

Figure 1. Labor productivity growth rate, broad sector averages (\%).

a. Waning growth, 1976-2008

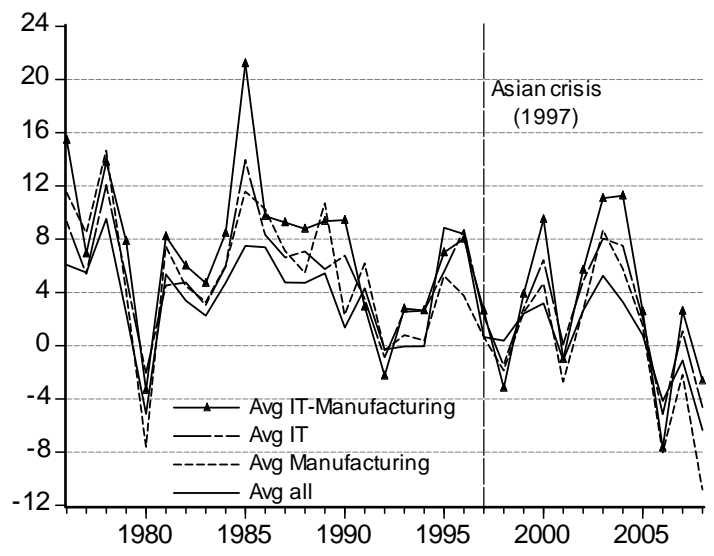

b. The aftermath of the Asian crisis, 1997-2008

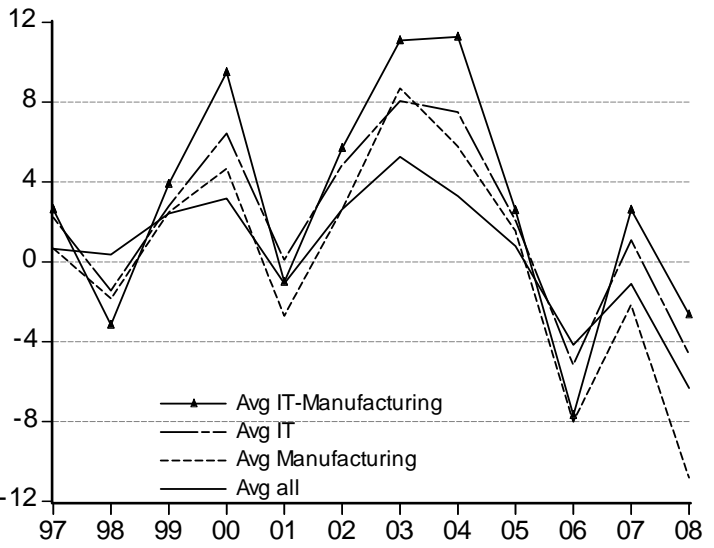

Since IT-Manufacturing industries were the least affected by the stifling economic conditions during the aftermath of the Asian crisis, we might want to know whether the industries there do share some specific trait that could explain their not so bad performances. IT industries are at the front of innovation and technological developments; offshoring and the labor income share. 
offshoring, in particular, can be thought of as a managerial innovation whereby firms, as with any other technological improvement, can become more efficient. We need now to measure offshoring before going any further.

Feenstra and Hanson (1996) first defined offshoring as the share of imported intermediate inputs in the total purchase of nonenergy inputs:

$$
o s_{i t}=\frac{I_{i t}}{Q_{t}} \frac{\Pi_{i t}}{D_{i t}}
$$

where $I_{i}$ is purchases of inputs $i$ by industry $i, Q$ is total inputs (excluding energy) used by $i, \Pi_{i}$ is total imports of good $i$, and $D_{i}$ its domestic demand. This is a narrow definition of offshoring for it only accounts for the intermediate inputs that firms within industry $i$ import from foreign firms in the same industry. I think this narrow measure makes for a better choice when using aggregate industry-level data, as it will diminish the aggregation-offshoring bias (on this issue see Fukao and Arai, 2013). Moreover, the first term in the definition above generally stems from the census data or Input-Output tables, while the second term, an economy-wide import share, is obtained from trade data. In our case, though, given that the data are taken from the same source, it is to expect that the measurement errors underlying the whole endeavor will be significantly reduced.

Figure 2. Offshoring intensity and IT-Manufacturing (\%).
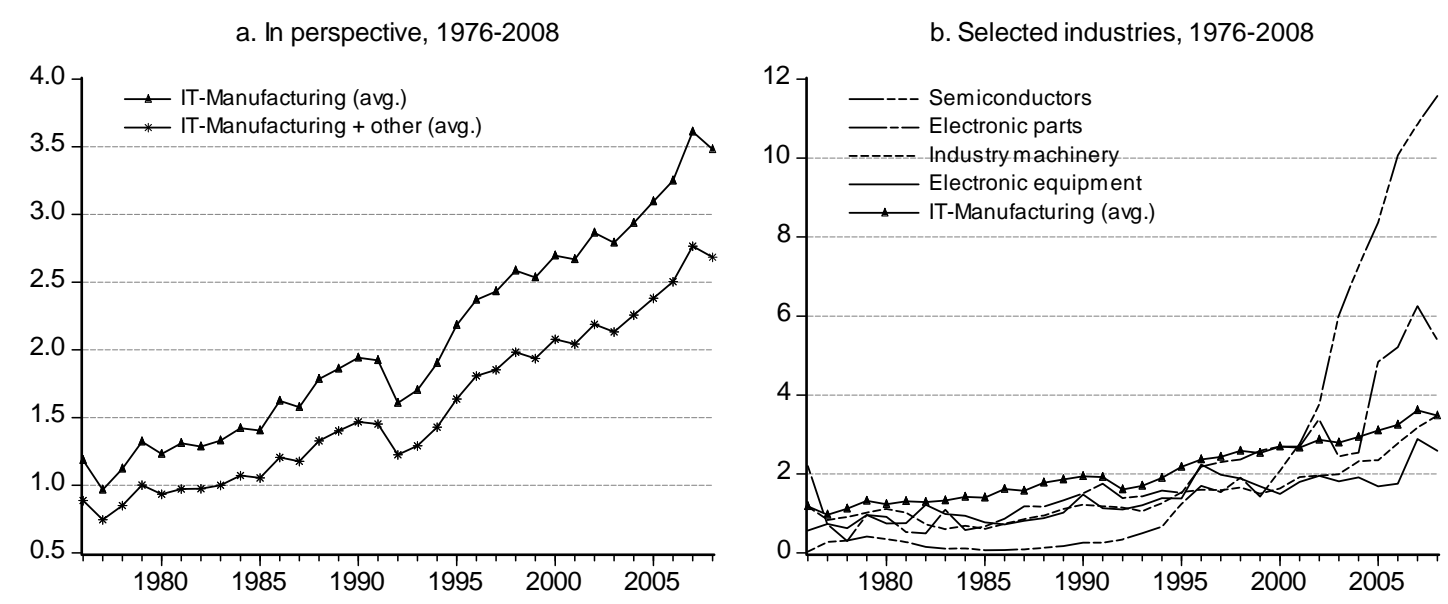

To drive the point home we need to highlight the trend of offshoring intensity of IT-Manufacturing industries among the most representative ones ${ }^{3}$ within the database.

\footnotetext{
${ }^{3}$ Among these were some non-IT Manufacturing and some IT non-Manufacturing. Note that highly developed industries, while being exposed to new technologies more rapidly, can also engage in what has come to be known as 'services' offshoring. The use of a narrow measure of offshoring prevents us from further breaking down the data into 'materials' and 'services offshoring', as it is sometimes done (see, for instance, Amiti and Wei, 2009, for the US, or Ito and Tanaka, 2010, for Japan).
} 
Figure 2a shows an important difference regarding these strategies. Furthermore, Figure $2 \mathrm{~b}$ zooms in on a small set of IT-Manufacturing industries that show different trends. Two of these industries, Semiconductors and Electronic Parts, are distinctly above the sector's average, whereas the other two, Industry machinery and Electronic equipment, are clearly below. Seemingly, highly productive IT-Manufacturing industries can have very different offshoring strategies.

With the exception of Industry machinery, the industries show a high growth rate of labor productivity during the post-crisis years (1997-present). It is left to wonder if offshoring might have had anything to do with these their experiences. In addition, we might want to know if offshoring played any role in the major changes that took place during those years (e.g. a significant drop in the labor income share).

The paper is organized as follows. Section 2 reflects on the decision to favor a time-series study instead of panel data analysis, and then goes over the details of the model. Section 3 discusses the data and methodology, shows the estimation of the model for the four industries discussed earlier, and then offers the diagnosis of our empirical analysis. Section 4 uses the models from the previous section to produce two dynamic accounting exercises regarding the effects of offshoring on productivity and the labor share; this section also offers some remarks on the possibility of skill upgrading. Section 5 concludes.

\section{Empirical framework}

\subsection{To pool or not to pool?}

The offshoring phenomenon is now under thorough examination within the academic field, with the majority of empirical work being conducted at the firm level. ${ }^{4}$ Due to the dimensions of these databases it is generally useful to pool the information somehow and estimate the effects on the average firm. This heterogeneity usually implies the use of GMM-type estimators, which can capture the differences among cross-sections more efficiently than pooled estimators and, at the same time, can address the potential endogeneity of the offshoring variable.

The JIP Database (RIETI, 2011), however, only collects industry level data for a wide set of activities in 108 Japanese industries. The natural strategy would be to pool all industries so as to estimate the effects on the average industry, just as is done for the firm. But when it comes to industry data we should be aware of the aggregation problem; that is, even when firms can be very different within the same industry, it is even more likely that these differences are more pronounced across industries. Under

\footnotetext{
${ }^{4}$ This is true for most of the references cited in the Introduction and footnote 2.
} 
these circumstances it will be more interesting to focus separately on the four ITManufacturing industries presented in the introduction while adopting a time-series perspective. In addition, industry-level data, as opposed to firm data, allows for an easier interpretation of the labor share effects of offshoring - something on which the literature has yet to provide some answers.

Firms in highly developed industries like the ones involved in this study do share several characteristics. Most of these characteristics come from the technological side, but some of them stem from the human resource management practices (see for instance Tsai, 2010, for the semiconductor industry). The point is that within each of the four industries we want to look into, there is a high degree of homogeneity as to downplay the possible aggregation bias $^{5}$ which is inherent to these studies. Of course, offshoring must still be instrumented as to address the endogeneity as in the case of panel estimation. The next section presents a simple setting that will be later used to carry out our dynamic accounting exercises.

\section{$2.2 \quad$ A simple model}

Here I propose a simple model that I will later use to track down the possible effects of offshoring on productivity growth. For this purpose I assume a Cobb-Douglas production function as below:

$$
Y=A(o s) K^{\alpha} N^{1-\alpha}
$$

where $Y$ is the output supplied by the firm, $K$ its stock of capital, $N$ its employment level, $\alpha$ and $1-\alpha$ the input elasticities, ${ }^{6}$ and $A$ the technology shifter - which is dependent on the offshoring index as defined above and satisfies that $A^{\prime}(o s)>0$, as offshoring can increase productivity in numerous ways (more on this below).

The marginal productivities in this case are given by:

$$
\begin{aligned}
M P_{K} & =\frac{\partial Y}{\partial K}=\alpha A(o s) K^{\alpha-1} N^{1-\alpha} \\
M P_{N} & =\frac{\partial Y}{\partial N}=(1-\alpha) A(o s) K^{\alpha} N^{-\alpha}
\end{aligned}
$$

Costs are defined as usual, as the total expenditures on inputs:

$$
C=R K+W N
$$

\footnotetext{
${ }^{5}$ The use of a narrow offshoring index, as explained earlier, contributes too in this direction.

${ }^{6}$ For reasons of exposition I will stick to the constant returns to scale hypothesis, but this should not be necessarily so. I will get back to this point later.
} 
where $R$ and $W$ are the input prices, real interest rate and real average wages. Cost minimization, given a certain level of output, determines that the ratio of marginal productivities be equal to the ratio of factor prices, that is $\frac{M P_{N}}{M P_{K}}=\frac{W}{R}$. Expressing the latter as $-\frac{M P_{N}}{M P_{K}}=-\frac{W}{R}$ implies that the slope of the isoquant (e.g. the marginal rate of substitution) and isocost are both equal. From the cost definition above we know that $K=\left(\frac{C}{R}\right)-\left(\frac{W}{R}\right) N$ and $\frac{\partial K}{\partial N}=-\left(\frac{W}{R}\right)$, and from (2) and (3) we know that $-\frac{M P_{N}}{M P_{K}}=-\left[\frac{(1-\alpha)}{\alpha} \frac{K}{N}\right]$. Finally, the cost minimization equilibrium condition is, as always:

$$
-\left[\frac{(1-\alpha)}{\alpha} \frac{K}{N}\right]=-\left(\frac{W}{R}\right)
$$

From here it is possible to derive the conditional factor demand for both capital and labor. Clearing up $N$ in the equilibrium condition above we get $N=\frac{(1-\alpha)}{\alpha} \frac{R}{W} K$, which we plug then into (1) to obtain the conditional factor demand for capital $K=$ $\left[A(o s)^{-1}\left(\frac{\alpha}{1-\alpha}\right)^{1-\alpha}\left(\frac{W}{R}\right)^{1-\alpha}\right] Y$. To obtain the conditional factor demand for labor we substitute the last expression into (1), which yields the following symmetrical expression:

$$
N=\left[A(o s)^{-1}\left(\frac{1-\alpha}{\alpha}\right)^{\alpha}\left(\frac{R}{W}\right)^{\alpha}\right] Y
$$

where employment is dependent, among other things, on the offshoring intensity index.

Aggregating (1) and (4) to the industry level, taking logs, and adding lags, errors, and the time subscript, we get an estimable system which is useful for tracking down the effects of offshoring on the industry's labor productivity:

$$
\begin{aligned}
y_{t} & =\alpha_{1}+\phi_{1} y_{t-1}+\beta_{1} n_{t}+\delta k_{t}+\lambda_{1} O s_{t}+\varepsilon_{1} \\
n_{t} & =\alpha_{2}+\beta_{2} n_{t-1}+\gamma w_{t}+\phi_{2} y_{t}+\lambda_{2} O s_{t}+\varepsilon_{2} \\
\theta_{t} & \simeq y_{t}-n_{t}
\end{aligned}
$$

where the small letters are the variables in logs with their corresponding coefficients, to wit: $\phi_{1}$ and $\beta_{2}$ the output and employment inertia coefficients, ${ }^{7} \beta_{1}$ and $\delta$ the employment and capital elasticities to output, $\gamma$ the wage elasticity to employment, $\lambda_{1}$ and $\lambda_{2}$ the offshoring semi-elasticities, and $\varepsilon_{1}$ and $\varepsilon_{2}$ the normally distributed errors with constant variance. Finally, let $\theta$ be the productivity of labor, which is defined as the ratio of output to the labor input. Since both output and labor are expressed in

\footnotetext{
${ }^{7}$ Introducing dynamics here allows us to conceive the existence of some frictions within the labor market. For the labor demand in particular, these can be interpreted as the adjustment costs employers face when significant training and firing costs are present - and these frictions are consistent with the presence of involuntary unemployment which, in turn, are an expected outcome of offshoring practices for some workers.
} 
logarithms we can approximate labor productivity by (7) - and then track down the changes in $\theta(\Delta \theta)$ as we set out to do originally.

I also expect the following signs for the coefficients: $0<\phi_{1}<1,0<\beta_{2}<1$, as to guarantee dynamic stability, ${ }^{8} \beta_{1}>0$ and $\delta>0,{ }^{9} \gamma<0$ (a negatively sloped labor demand), $\phi_{2}>0$, and $\lambda_{1}>0$ and $\lambda_{2}<0$. On the latter two coefficients a few remarks are in order.

Amiti and Wei (2009) identify four possible channels through which offshoring can affect productivity: (i) static efficiency gain, (ii) restructuring, (iii) learning externalities, and (iv) variety effects. First, when firms decide to relocate activities to overseas locations they relocate the less efficient parts and average productivity increases due to a compositional effect. Second, the remaining workers may become more efficient if firms can restructure in a way that pushes out the technology frontier. Third, firms can learn to improve the way activities are performed by importing services. And fourth, productivity could increase due to the use of new material or service input varieties. The model above cannot distinguish the exact channel of the productivity gain arising from offshoring, yet we can assume that these are embedded into $\lambda_{1}$ and $\lambda_{2}$.

\section{Empirical analysis}

\subsection{Data and methodology}

The data I use for this study come from the JIP Database (RIETI, 2011), ranging from 1970 to 2008 and including 108 industries from different branches of economic activity — services and manufacturing being the main categories. The four industries under study are categorized as both manufacturing and IT-intensive industries.

${ }^{8}$ For a dynamic model of the type:

$$
\mathbf{A}_{0} \mathbf{y}_{t}=\sum_{i=1}^{n} \mathbf{A}_{i} \mathbf{y}_{t-i}+\sum_{i=0}^{n} \mathbf{D}_{i} \mathbf{x}_{t-i}+\varepsilon_{t}
$$

where $\mathbf{y}_{t}$ is a vector of endogenous variables, $\mathbf{x}_{t}$ a vector of exogenous variables, $\mathbf{A}_{i}$ 's and $\mathbf{D}_{i}$ 's are coefficient matrices, and $\varepsilon_{t}$ a vector of strict white noise error terms; then the dynamic system above is stable if, for given values of the exogenous variables, all the roots of the determinantal equation (where $B$ is the backshift operator)

$$
\left|\mathbf{A}_{0}-\mathbf{A}_{1} B \ldots-\mathbf{A}_{n} B^{n}\right|=0
$$

lie outside the unit circle. The estimated equations below satisfy this condition.

${ }^{9}$ The constant returns to scale hypothesis would require that $\frac{\beta_{1}}{\left(1-\beta_{2}\right)}+\frac{\delta}{\left(1-\beta_{2}\right)}=1$. Notice that down below I do not constrain the equations as to fulfill this hypothesis (the estimation results are not that different from one another anyhow). Non-constant returns would imply that (1) and (4) should be slightly changed but this is of no real importance for the empirical analysis below. 
Table 2: Summary statistics, 1976-2008.

\begin{tabular}{|c|c|c|c|c|}
\hline Industry / Variable & Mean & Max. & Min. & Std. $d v$ \\
\hline \multicolumn{5}{|l|}{ Semiconductors } \\
\hline$N$ : employment (workers) & 145,192 & 236,251 & 7,252 & 80,217 \\
\hline$W:$ average real wages (million yen) & 4.12 & 16.46 & 1.06 & 3.38 \\
\hline$Y:$ real output (million yen) & $1,245,543$ & $4,274,040$ & 14,160 & $1,145,483$ \\
\hline$K:$ real net capital stock (million yen) & $4,715,221$ & $12,665,640$ & 402,851 & $3,764,188$ \\
\hline os : offshoring index $(\%)$ & 2.28 & 11.57 & 0.04 & 3.45 \\
\hline$\Delta \theta:$ labor productivity growth rate $(\%)$ & 9.58 & 77.24 & -33.93 & 18.85 \\
\hline \multicolumn{5}{|l|}{ Electronic parts } \\
\hline$N$ : employment (workers) & 463,964 & 570,711 & 213,386 & 118,487 \\
\hline$W:$ average real wages (million yen) & 3.05 & 7.54 & 0.84 & 2.01 \\
\hline$Y:$ real output (million yen) & $2,412,535$ & $6,686,689$ & 240,717 & $1,769,861$ \\
\hline$K:$ real net capital stock (million yen) & $2,928,973$ & $6,185,476$ & 526,448 & $1,994,487$ \\
\hline os : offshoring index $(\%)$ & 2.03 & 6.25 & 0.31 & 1.50 \\
\hline$\Delta \theta:$ labor productivity growth rate $(\%)$ & 8.04 & 36.89 & -30.39 & 14.33 \\
\hline \multicolumn{5}{|l|}{ Industry machinery } \\
\hline$N$ : employment (workers) & 436,490 & 503,170 & 351,355 & 32,846 \\
\hline$W:$ average real wages (million yen) & 4.86 & 6.64 & 3.33 & 0.92 \\
\hline$Y:$ real output (million yen) & $2,819,787$ & $3,841,516$ & $1,550,403$ & 642,478 \\
\hline$K:$ real net capital stock (million yen) & $5,594,873$ & $9,077,593$ & $2,217,262$ & $2,241,890$ \\
\hline os : offshoring index $(\%)$ & 1.45 & 3.48 & 0.60 & 0.72 \\
\hline$\Delta \theta:$ labor productivity growth rate $(\%)$ & 1.92 & 19.57 & -13.45 & 6.83 \\
\hline \multicolumn{5}{|l|}{ Electronic equipment } \\
\hline$N$ : employment (workers) & 113,889 & 146,309 & 72,260 & 20,440 \\
\hline$W:$ average real wages (million yen) & 5.28 & 11.59 & 0.78 & 3.09 \\
\hline$Y:$ real output (million yen) & 882,535 & $1,770,692$ & 153,761 & 475,369 \\
\hline$K:$ real net capital stock (million yen) & $1,006,303$ & $1,842,645$ & 218,022 & 500,279 \\
\hline os : offshoring index $(\%)$ & 1.37 & 2.89 & 0.57 & 0.59 \\
\hline$\Delta \theta:$ labor productivity growth rate $(\%)$ & 14.77 & 323.61 & -58.43 & 60.57 \\
\hline
\end{tabular}

Note: 33 observations (1976-2008); $Y$ is gross value added (at factor prices), and $Y, K$, and $W$ were deflated using the GDP deflator (JIP Database 2011). Variables not in logs.

Table 2 summarizes the main information on the time-series I use in the estimation below. Notice that, as in all tables and figures, the industries are ordered by their 'offshoring intensity', namely: $1^{o}$ semiconductors, $2^{o}$ electronic parts, $3^{\circ}$ industry 
machinery, $4^{o}$ electronic equipment. ${ }^{10}$

The estimation strategy involves the Autoregressive Distributed Lagged (ARDL) approach by Pesaran (1997), Pesaran and Shin (1999), and Pesaran et al. (2001). The ARDL yields consistent estimates for the short and long-run that can used when regressors are either $\mathrm{I}(1)$ or $\mathrm{I}(0)$, as it is our case. For each industry I estimate a twoequation system that allows me to track down the changes in labor productivity and assess the contribution of offshoring.

Equations (5) and 6 are first estimated separately and evaluated against a set of diagnostic tests. Both equations are then estimated jointly with the three-stage least squares method (3SLS), which accounts for potential endogeneity and cross-equation correlation. The potential endogeneity of some of the variables is something we should take into consideration. In particular for the offshoring index, endogeneity can be further magnified by the presence of measurement errors. To solve for this we instrument wages, capital, and the offshoring index, with the past values of wages and capital. ${ }^{11}$

As a final step we should check on the validity of the long-run relationships among the growing variables in the models. For this I reparametrize the estimated equations as error correction models (ECMs) and obtain the cointegrating vectors (CVs) among the I(1) variables. Even when the ECM on its own gives proof of cointegration of the time-series involved, I also use Johansen's cointegration procedure (Johansen, 1988) to check whether the long-run relationships conform with those obtained through the estimation of the two-equation model. I will get back to this later.

\subsection{Estimation}

Tables 3a to 3d present the two-equation models for all four industries. Note that in all cases the coefficients are properly signed (e.g. as hypothesized above), and in most cases turn out significant at conventional levels. The offshoring coefficients, however, turn out with a lower significance and, in some cases, are non-significant at all (it is denoted with an ${ }^{*}$ in the tables). ${ }^{12}$ For the Semiconductors industry they are significant

\footnotetext{
${ }^{10}$ The broad economic sectors in the JIP Database correspond to the codes: 1-7 for primary industries, 8-59 for manufacturing, 60-61 construction, 62-66 energy, and 67-108 services. Our four industries of interest are coded and fully labeled as follows: 51. Semiconductor devices and integrated circuits; 52. Electronic parts; 50. Electronic equipment and electric measuring instruments; and 42. General industry machinery. See Appendix A for a correspondence between these four industries in the JIP and other well-known databases and international classifications.

${ }^{11}$ We also try with other exogenous instruments for the offshoring index in particular, namely: the investment in information technology used to produce software and hardware, but the results are not changed significantly (see Appendix B). Moreover, the endogeneity of offshoring does not pose so serious a problem for industry level data as it does for firm level data. Regardless, the validity of the instruments and of the overidentifying restrictions must still be checked - this I do below by means of a conventional Sargan test.

${ }^{12}$ The dynamic structure of all four models is rather unpromising too. However, it should be stressed that the introduction of dynamics is due to the fact that they are a source of frictions which can bring
} 
at $5 \%$ in both equations (Table 3a); for the Electronic parts industry it is significant only in the production function at $5 \%$ level (Table 3b); for Industry machinery it is only (yet highly) significant in the labor demand equation, at 1\% level (Table 3c); and for Electronic equipment it is neither significant in the labor demand nor in the production function.

Because the number of instruments exceeds the number of regressors in the proposed models we must test for the validity of the overidentifying restrictions. Under the null hypothesis that these are valid, the Sargan statistic is distributed as $\chi_{(k-p)}^{2}$ with $k$ the number of instruments and $p$ the number of estimated coefficients. Not rejecting the test at conventional levels (e.g. above 5\%) is indicative of the exogeneity of the instruments used. ${ }^{13}$

In spite of these not totally convincing results, it should be noted that all offshoring coefficients are properly signed. That is, in all cases offshoring seems to exert a negative impact on the demand for labor and a positive one on production. This is in agreement with the economic intuition as pointed out before (see Amiti and Wei, 2009). Even when our goal is to track down the changes in labor productivity that have taken place in the past few years, it is possible here to come up with an extent of the magnitude of the effects involved in the different sectors. But for this it will be needed to get the long-run elasticities to make the effects comparable among the industries.

Table 4 shows the short and long-run elasticities for the models. Notice that we refer to these as semi-elasticities because the offshoring index is not expressed in logarithms. ${ }^{14}$ The columns labeled as $\epsilon_{n-o s}^{S R}$ and $\epsilon_{y-o s}^{S R}$ correspond to the short-run semi-elasticities as estimated in Tables 3a to 3d, while the columns labeled as $\epsilon_{n-o s}^{L R}$ and $\epsilon_{y-o s}^{L R}$ correspond to the long-run semi-elasticities and are calculated simply as $\epsilon_{n-o s}^{L R}=\frac{\lambda_{1}}{\left(1-\phi_{2}\right)}$ and $\epsilon_{y-o s}^{L R}=$ $\frac{\lambda_{2}}{\left(1-\beta_{2}\right)}$.

When it comes to "employment loss" the effects are only significant within Semiconductors and Industry machinery, with larger effects on the latter. These effects should come as no surprise since even when these industries qualify as IT, they entail different activities and, hence, rather different occupational skills (see Appendix A). It can be safely argued that for Industry machinery the skill requirements are far less important than for any of the other three. Therefore, we should expect that workers within this particular industry be more prone to suffer the negative effects of offshoring activities. On the other hand, offshoring seems to have positive and significant effects only within the Semiconductors and Electronic parts industries, with larger effects on the latter.

about involuntary unemployment - and this is consistent with the offshoring story.

${ }^{13}$ See Appendix B for an alternative estimation with additional instruments.

${ }^{14}$ This responds only to presentation purposes, and it should be interpreted as the percentage change (\%) in the dependent variable, on average, when the offshoring index increases by one percentage point. 


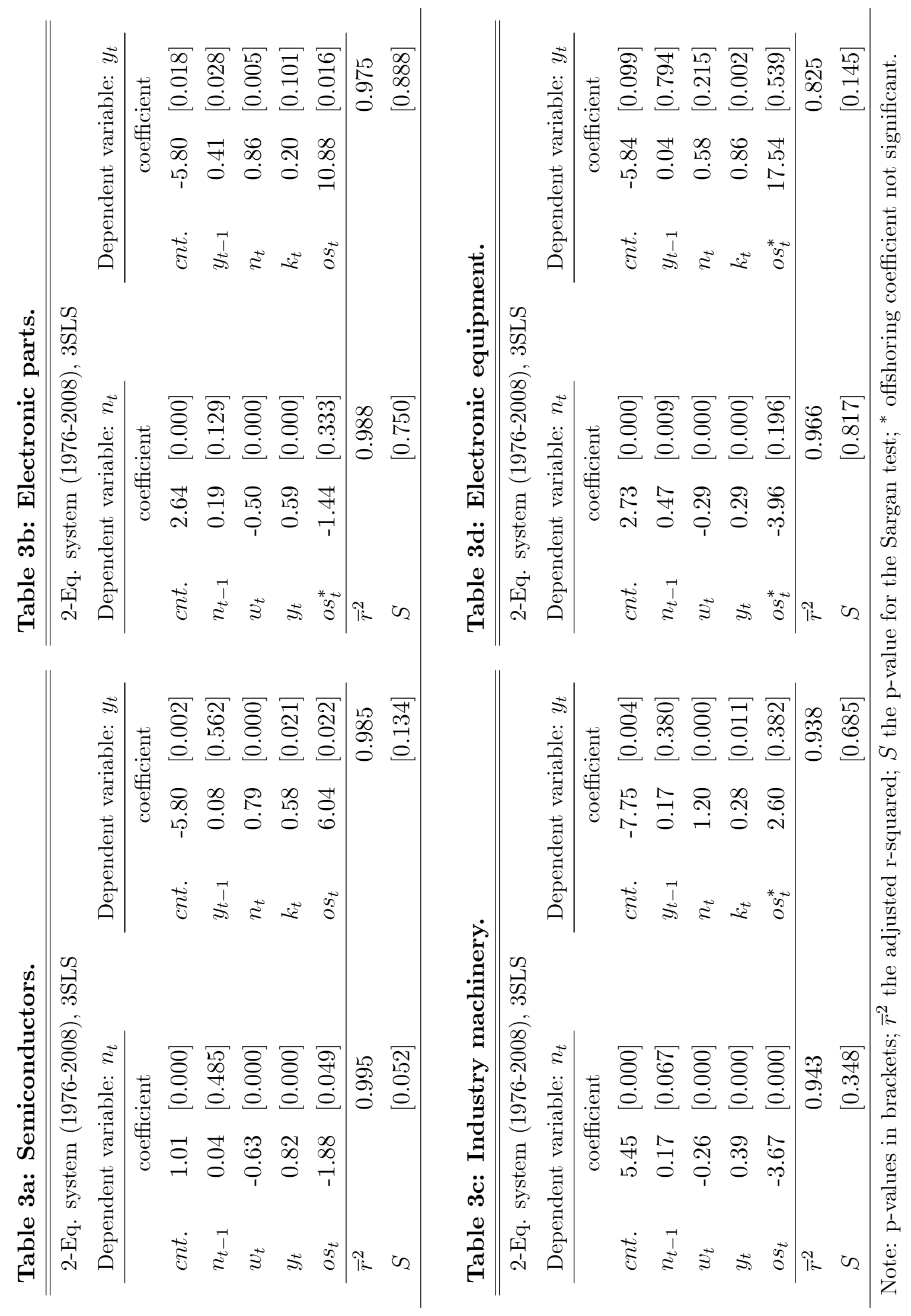


Table 4: Offshoring short and long-run semi-elasticities.

\begin{tabular}{lcccccc}
\hline \hline & $\epsilon_{n-o s}^{S R}$ & $\epsilon_{n-o s}^{L R}$ & & $\epsilon_{y-o s}^{S R}$ & $\epsilon_{y-o s}^{L R}$ \\
\cline { 2 - 3 } \cline { 5 - 6 } Semiconductors & -1.88 & -1.97 & & 6.04 & 6.59 \\
Electronic parts & $-1.44^{*}$ & $-1.78^{*}$ & & 10.88 & 18.33 \\
Industry machinery & -3.67 & -4.41 & & $2.60^{*}$ & $3.14^{*}$ \\
Electronic equipment & $-3.96^{*}$ & $-7.52^{*}$ & & $17.54^{*}$ & $18.36^{*}$ \\
\hline
\end{tabular}

* Not significant.

\subsection{Diagnosis}

A first check on the estimated models is given by Figure 3. There it is shown how the models track the changes in labor productivity for the whole sample of study (19762008). Do note however that only Figures 3a (Semiconductors) and 3d (Electronic equipment) seem to offer a relatively good fit; yet this should not be problematic since we are tracking down a growth rate that we defined as the difference of two endogenous variables - hence the not-so-perfect fit in some cases. The gray-shaded areas represent the sub-period of interest for our next empirical exercise, which goes from the beginning of the Asian crisis (1997) up to the end of the sample (2008).

A second check is offered in Table 5, which shows the misspecification and stability tests for the four two-equation systems. Misspecification tests include: heteroskedasticity (HET) and conditional heteroskedasticity (ARCH) tests; Lagrange multiplier test for serial correlation (SC); Ramsey's linearity test (LIN); and Jarque-Bera test for normality (NOR). The stability tests are the Cusum and Cusum², ensuring structural stability of the estimated equations. With a very few exceptions (denoted with an ${ }^{*}$ ) the proposed tests are easily passed in all models.

A final check involves the cointegration analysis underlying time-series analysis. ${ }^{15}$ To see if the series cointegrate, and as an alternative to the ARDL approach, I present the results obtained by Johansen's multivariate method - which has been proved to outperform other conventional techniques (e.g. Engle-Granger), for it can deliver all possible CVs. For both equations in each of our four models I estimate a VAR specification featuring the same variables, lag order, and sample period, as those used in the ARDL approach. The optimal model selection for the VAR specifications (e.g. intercepts or trends, both restricted and unrestricted, or any possible combination) is done via Pantula principle (Johansen, 1992, Pantula 1989), and involves moving from the more to the less restrictive of the specifications.

\footnotetext{
${ }^{15}$ The results on the unit root tests of the series involved are available on request.
} 
Figure 3. Productivity growth rate: Actual and fitted values.
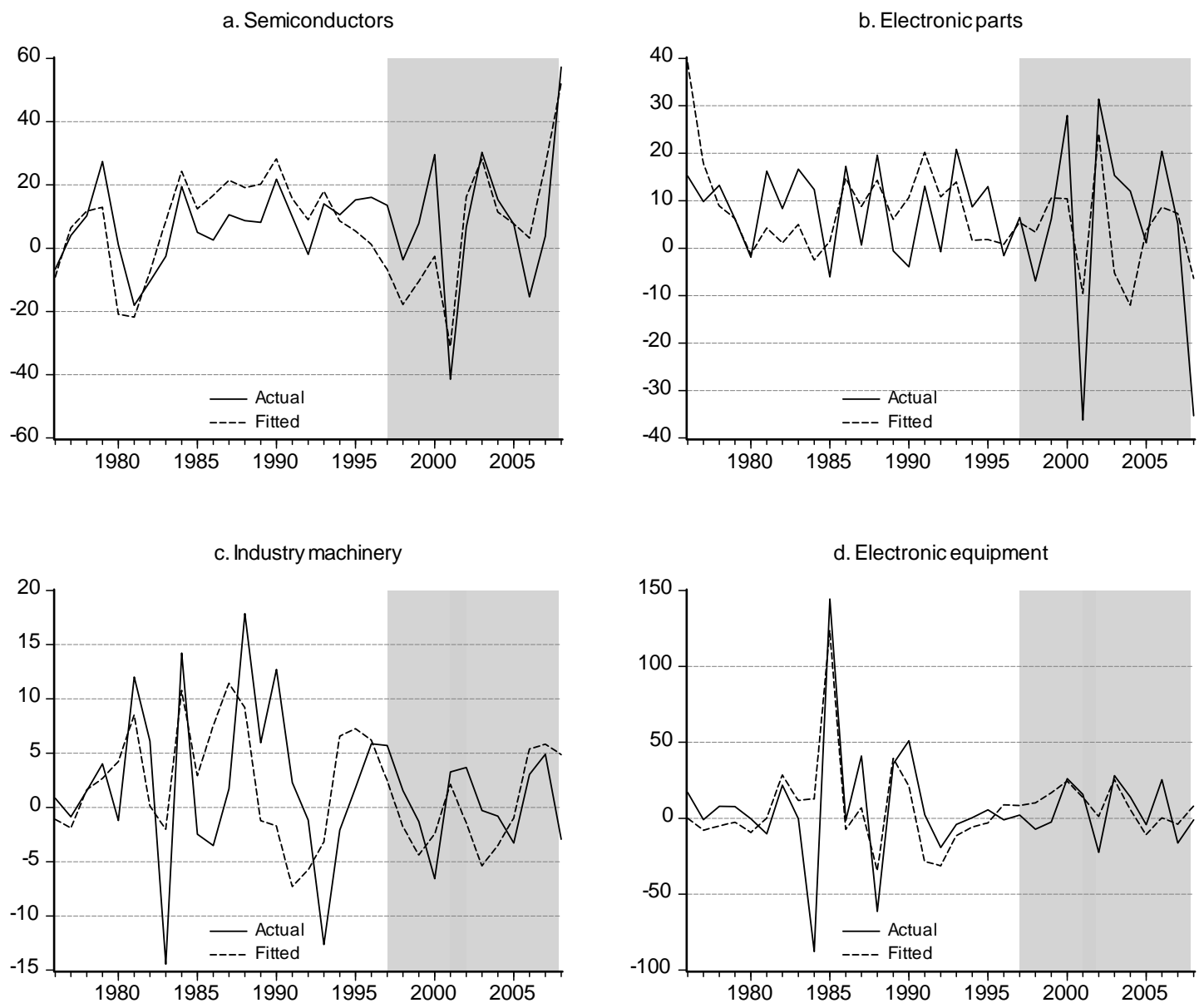

Table 6 presents the results of both analyses. On the first column under the ARDL approach we find the results of the reparametrized equations as ECMs. Negative and significant coefficients imply cointegration in all cases. The second and third columns, in turn, show the values of the CVs for the ARDL approach and Johansen's method. The last column displays the results of an LR test, distributed as a $\chi_{(q)}^{2}$ with $q$ the number of restrictions, when restricting the values under Johansen to those of the long-run ARDL values. We can see from this column that none of the restrictions can be rejected at conventional critical values, indicating cointegration among the growing variables in each equation. 


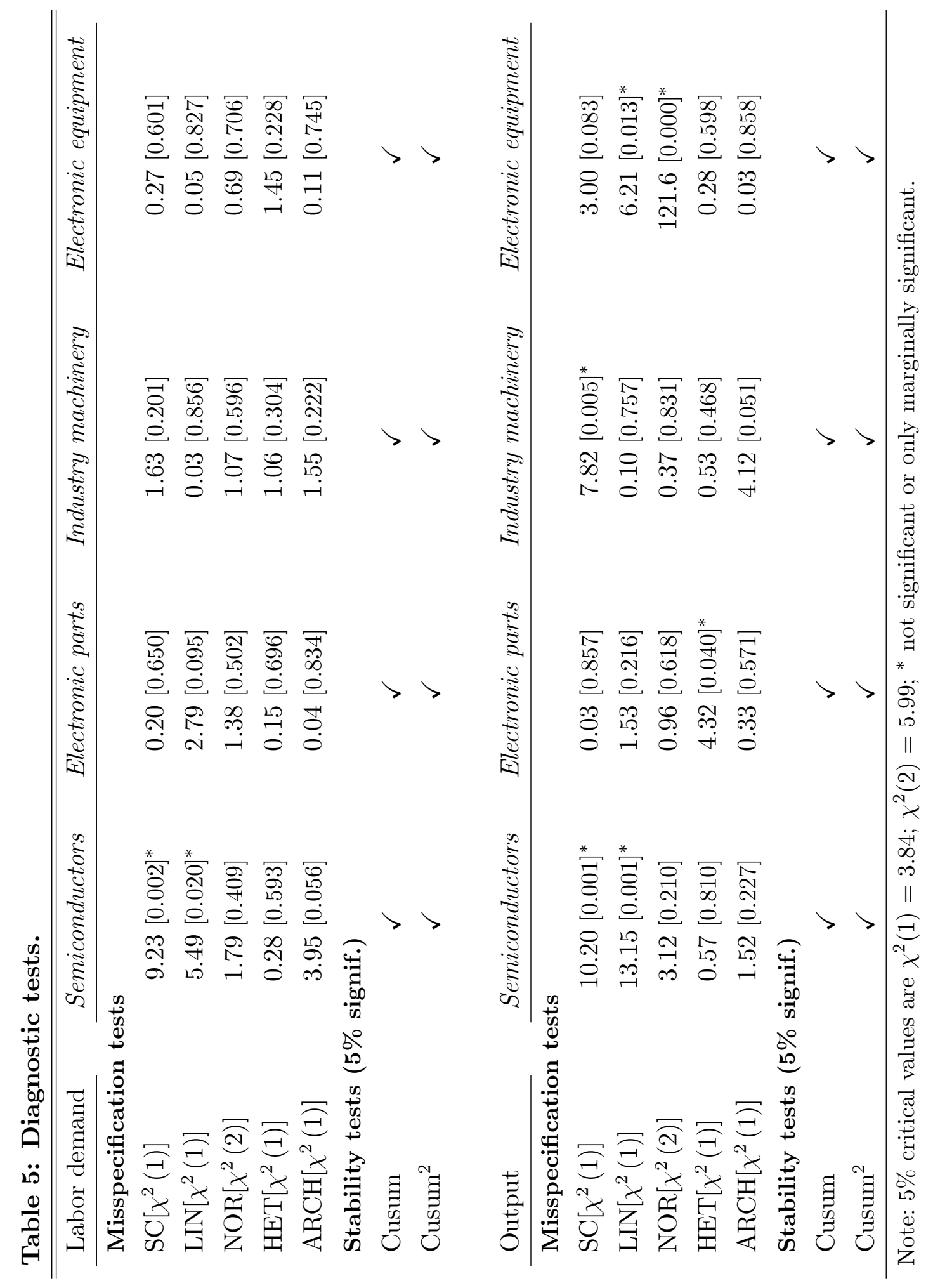


Table 6: Validity of the long-run relationships.

\begin{tabular}{|c|c|c|c|c|c|c|c|}
\hline \multicolumn{4}{|c|}{ ARDL } & \multirow{2}{*}{\multicolumn{3}{|c|}{ Johansen }} & \multirow[t]{2}{*}{ LR test } \\
\hline$e c m_{t-1}$ & & $C V$ & & & & & \\
\hline $\begin{array}{l}{[L D]} \\
\text { Semiconductors: }\end{array}$ & $(n$ & $w$ & $y$ & $(n$ & $w$ & $y \quad)$ & \\
\hline $\begin{array}{l}-0.91(0.000) \\
\text { Electronic parts: }\end{array}$ & $(1$ & -0.73 & $0.87)$ & $(1$ & -0.90 & $0.94)$ & $\chi^{2}(2)=3.16[0.205]$ \\
\hline $\begin{array}{l}-0.61(0.000) \\
\text { Ind. machinery: }\end{array}$ & $(1$ & -0.68 & $0.74)$ & $(1$ & -0.66 & $0.72)$ & $\chi^{2}(3)=2.92[0.404]$ \\
\hline $\begin{array}{l}-0.73(0.000) \\
\text { Electronic eqpmt: }\end{array}$ & $(1$ & -0.36 & $0.48)$ & $(1$ & -0.24 & $0.49)$ & $\chi^{2}(2)=4.01[0.134]$ \\
\hline$-0.53(0.000)$ & $(1$ & -0.60 & $0.56)$ & $(1$ & -0.62 & $0.54)$ & $\chi^{2}(2)=3.90[0.142]$ \\
\hline $\begin{array}{l}{[\text { OUT }]} \\
\text { Semiconductors: }\end{array}$ & $(y$ & $n$ & $k \quad)$ & $(y$ & $n$ & $k \quad)$ & \\
\hline $\begin{array}{l}-0.90(0.000) \\
\text { Electronic parts: }\end{array}$ & $(1$ & 0.77 & $0.76)$ & $(1$ & 0.50 & $1.08)$ & $\chi^{2}(2)=1.93[0.381]$ \\
\hline $\begin{array}{l}-0.46(0.014) \\
\text { Ind. machinery: }\end{array}$ & $(1$ & 1.51 & $0.35)$ & $(1$ & 0.83 & $0.28)$ & $\chi^{2}(2)=2.60[0.272]$ \\
\hline $\begin{array}{l}-0.86(0.000) \\
\text { Electronic eqpmt: }\end{array}$ & $(1$ & 1.39 & $0.36)$ & $(1$ & 1.50 & $0.46)$ & $\chi^{2}(2)=4.39[0.111]$ \\
\hline$-0.85(0.000)$ & $(1$ & 0.30 & $1.07)$ & $(1$ & 0.79 & $0.85)$ & $\chi^{2}(2)=4.01[0.134]$ \\
\hline
\end{tabular}

Notes: $C V=$ cointegrating vector; $L D$ is labor demand, OUT is output; p-values in parentheses; and $5 \%$ critical values for the LR test are: $\chi^{2}(2)=5.99, \chi^{2}(3)=7.82$.

\section{Effects of offshoring}

\subsection{Labor productivity}

We can now use the estimated models to obtain the contributions of the offshoring index to the growth in labor productivity. These contributions are computed through a dynamic simulation of the estimated models as follows: we first fix the offshoring index in each industry at the level of certain arbitrary year, then we solve the model, and finally we retrieve the new path of the endogenous variable. For us that initial year corresponds with the beginning of the Asian crisis in 1997 - as the gray shaded areas indicate above in Figure 3. The endogenous variable is the labor productivity growth rate $(\Delta \theta)$ — as was shown to perform badly from 1997 onwards.

To illustrate this I plot the results of these simulations as Figures 4a, 5a, 6a, and $7 \mathrm{a}$, along with the simulated trajectories of the offshoring index as Figures $4 \mathrm{~b}, 5 \mathrm{~b}, 6 \mathrm{~b}$, and $7 \mathrm{~b}$. The first set of figures ("a") show both the actual trajectory of the growth rate of labor productivity and the simulated trajectory had the offshoring index remained at the 1997 value. Notice that the average growth rates for both trajectories are made 
explicit in the figures. The second set of figures ("b") show both the actual trajectory of the offshoring index with the trajectory fixed at the 1997 value. Therefore, what we get from Figures 4 to 7 is the individual contribution of offshoring to the changes in labor productivity or, in other words, what the growth rate of productivity would have been if offshoring had remained at its 1997 level. As can be seen from the figures, for all four industries offshoring went up during 1997-2008, for some more and for others less.

Figure 4. Semiconductors: Offshoring contribution to productivity.
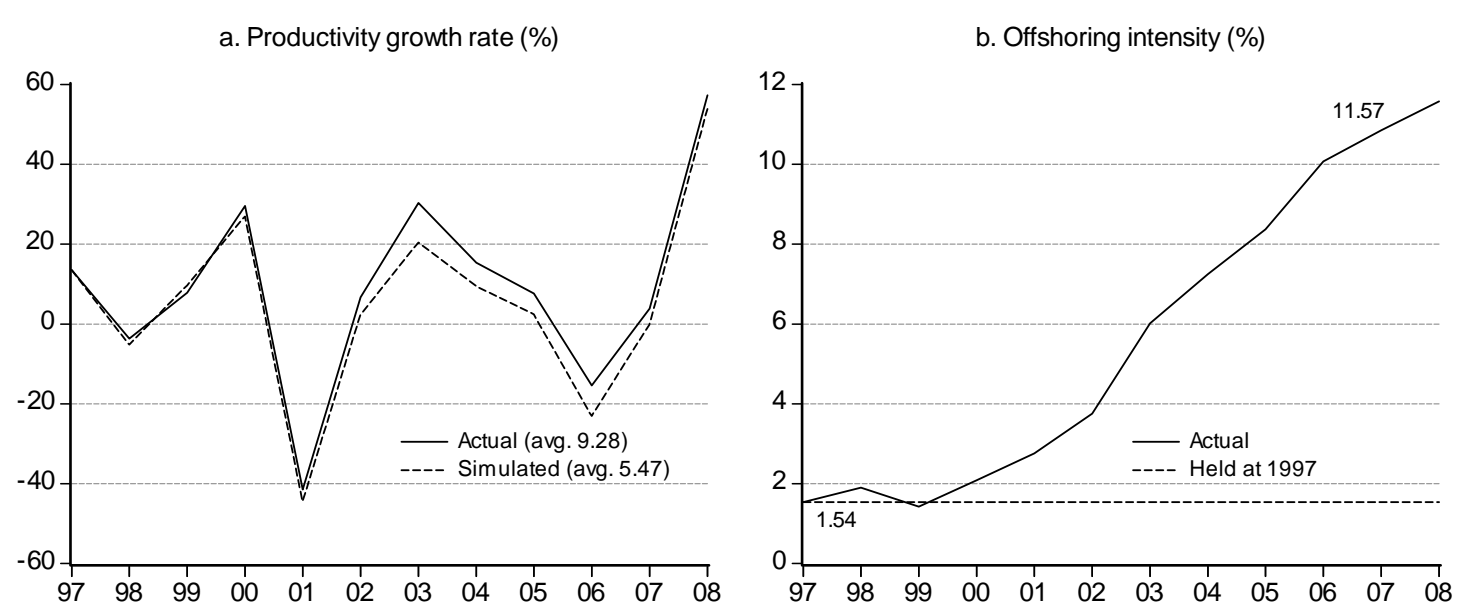

Firms within the Semiconductors industry are, according to the data, highly involved in offshoring practices. Being perhaps among the most technologically oriented industry within and outside of Japan, the Japanese semiconductor sector has achieved significantly high levels of offshoring intensity in the past few years (Figure 4b), especially through the hands of the big players like Toshiba and Renesas. ${ }^{16}$ Our analysis suggests that had offshoring remained unchanged at its 1997 level then the productivity growth rate would have been lower (5.47 on average, instead of 9.28 , as seen in Figure $4 a)$.

Most multinational companies can be said to have interests in several industries. Such is the case, for instance, of Panasonic, Fujistsu, Sony, Toshiba and the Hitachi Group, just to new a few, with interests in several and varied industries. However, their contribution over the last years to the growth of the electronics industry cannot go unnoticed. ${ }^{17}$ As for the offshoring trend it is positive but not as important as in

\footnotetext{
${ }^{16}$ These two alone account for around $8 \%$ share of the international market (iSuppli Corporation supplied rankings, 2011). See Wakasugi (1988) for a case study on the evolution of the Semiconductors industry in Japan and how it acquired its international competitive capability through fierce competition.

${ }^{17}$ Japanese electronics firms are highly respected worldwide, as is documented by the OECD In-
} 
the Semiconductors industry (see Figures $5 \mathrm{~b}$ and $7 \mathrm{~b}),{ }^{18}$ yet it is more than enough for having a larger impact on productivity growth (see Figures 5a and 7a; and see also Yamada, 1990). The traditional reluctance of Japanese firms in general, and of those within the electronics sector (broadly defined) in particular, is starting to show signs of breaking down not only because of the more aggressive Asian competitors but also because of the increased risk profile of many firms in Japan's post-earthquake and post-tsunami economy (see WSJ, 2011).

\section{Figure 5. Electronic parts: Offshoring contribution to productivity.}
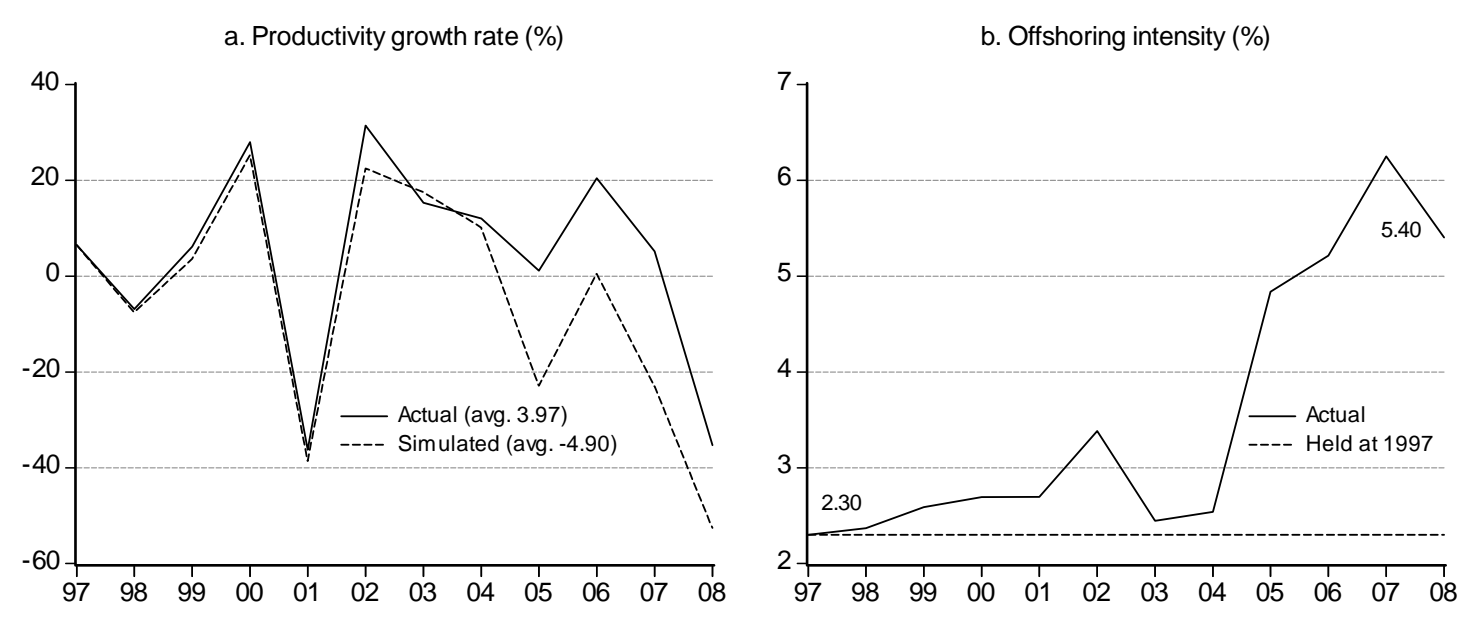

On the other hand, Industry machinery firms (Figures 6a and 6b) are not in the least affected by the positive trend of offshoring in recent years. According to our analysis, labor productivity is unaffected in spite of the considerable increase in offshoring. Moreover, and as suggested before, offshoring might well not be employment friendly for this particular industry. Indeed, for reasons of costs and proximity many Japanese firms are starting to relocate their low-end activities to China (where large numbers of Japanese speakers can be found), as well as to some other Southeast Asian countries with an abundant and cheap labor force. ${ }^{19}$

formation Technology Outlook (2010). There, 44 economies were reported as bases for the top 250 ICT-firms in 2009: 75 (30\%) were based in the United States, 52 were based in Japan and 18 in Chinese Taipei.

${ }^{18}$ Firms within the Electronics parts and Electronic equipment industries, as defined in the Appendix A, cannot be easily distinguished from one another for their many daily activities frequently overlap both classifications.

${ }^{19}$ See the Forrester report (2007) for an analysis on the offshoring opportunities of Japan in China and India; and Ito and Tanaka (2010) for evidence on Japan which is consistent with this section. 
Figure 6. Industry machinery: Offshoring contribution to productivity.

a. Productivity growth rate (\%)

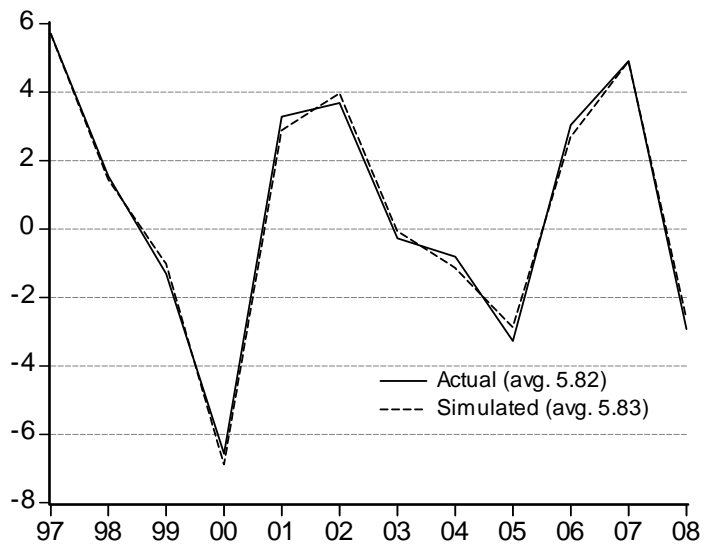

b. Offshoring intensity (\%)

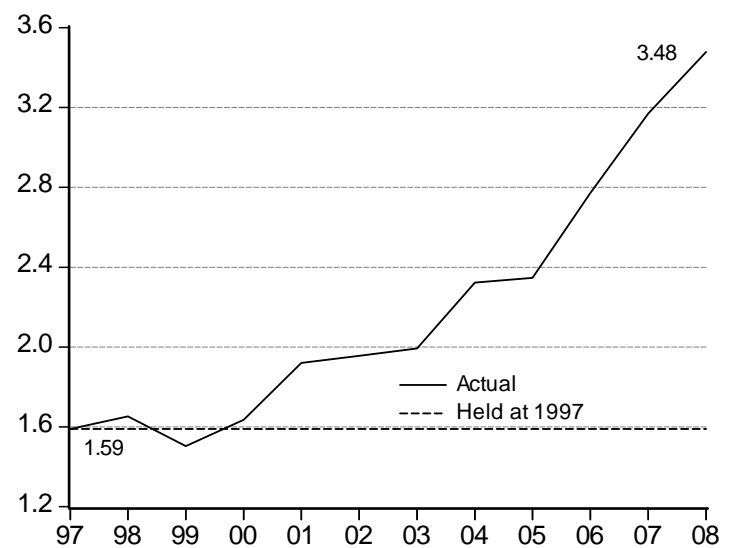

Table 7 sums up the results of the dynamic accounting exercise so far. The first two columns show the values of the offshoring index for 1997 and 2008 respectively, which correspond to the two ends of the simulation period (see Figure 3 above). The next columns exhibit, respectively, the difference for that period, the contribution in terms of productivity growth rate, and the contribution per percentage point (p.p.).

Figure 7. Electronic equipment: Offshoring contribution to productivity.
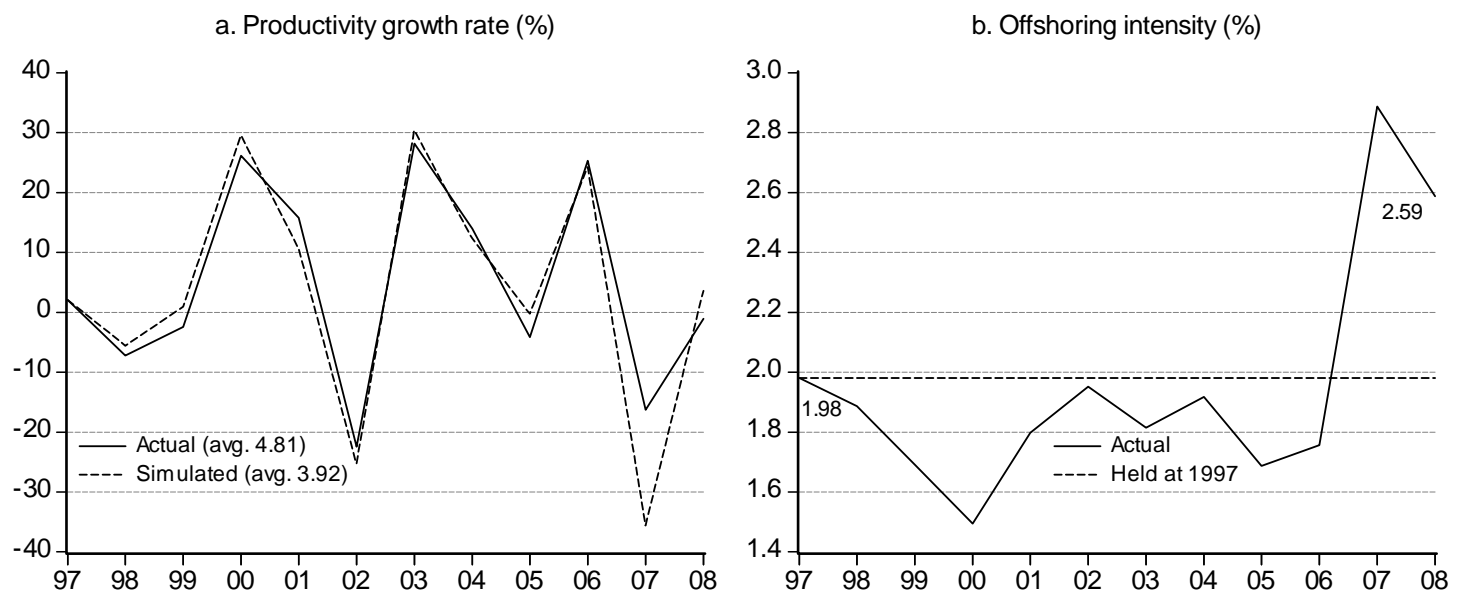

As noted before, the Semiconductors industry is the only one showing significant estimated coefficients of the offshoring variable in both equations. In terms of contribution to productivity, however, both electronics industries produce larger numbers - yet the contribution of the Electronic equipment industry should be interpreted carefully due to the lack of significance of both coefficients. Lastly, we found no effect on productivity for the less IT-intensive industry, labeled as Industry machinery. 
Table 7: Offshoring contribution to productivity.

\begin{tabular}{lccccc}
\hline \hline & $o s_{1997}$ & os $_{2008}$ & $\Delta o s^{*}$ & Cont. to $\Delta \theta^{* *}$ & Cont. per 1 p.p. \\
\cline { 2 - 6 } Semiconductors & 1.54 & 11.57 & 10.03 & 3.81 & 0.38 \\
Electronic parts $^{\dagger}$ & 2.30 & 5.40 & 3.10 & 8.87 & 2.86 \\
Industry machinery $^{\dagger}$ & 1.59 & 3.48 & 1.89 & $\simeq 0$ & $\simeq 0$ \\
Electronic equipment $^{\ddagger}$ & 1.98 & 2.59 & 0.61 & 0.89 & 1.46 \\
\hline
\end{tabular}

${ }^{*}$ In percentage points; ${ }^{* *}$ actual minus simulated average (Figs. 4a, 5a, 6a, 7a).

$\dagger$ Offshoring coefficients partially significant or ${ }^{\ddagger}$ not significant in estimation.

\subsection{Skill upgrading and the labor share}

A broad branch of literature ${ }^{20}$ deals with offshoring as a source of skill-biased technological change (SBTC), where high-skill workers see their wages increase relatively to that of low-skill ones due to their greater ability to adapt to the new technologies. In other words, SBTC can be understood as a change in relative wages reflecting a change in productivity levels (or skill upgrading).

The two separate regressions in Table 8 throw some light on the matter. Using the data from our four industries we run a regression of the relative wages on the offshoring index. Table 8a shows the relative wages of high to low-skill IT-Manufacturing industries regressed on the offshoring index of high-skill IT-Manufacturing industries, while Table $8 \mathrm{~b}$ shows the relative wages of low to high-skill regressed on the offshoring of low-skill. ${ }^{21}$

Table 8: Skill upgrading.

Single-eq. (1976-2008), OLS

(a) Dependent variable: $w_{h, t} / w_{l, t}$ coefficient

\begin{tabular}{lrllrl} 
cnt. & 0.33 & {$[0.000]$} & cnt. & 2.83 & {$[0.000]$} \\
$o s_{h, t}$ & 25.04 & {$[0.000]$} & $o s_{l, t}$ & -84.84 & {$[0.000]$} \\
\hline $\bar{r}^{2}$ & 0.933 & & & 0.641
\end{tabular}

$\begin{array}{lll}\text { s.e. } & 0.119 & 0.454\end{array}$ (b) Dependent variable: $w_{l, t} / w_{h, t}$ coefficient

Note: $\mathrm{p}$-values in brackets; $\bar{r}^{2}$ the adjusted r-squared; s.e. the standard error; $w$ average real wages; $h$ high-skill and $l$ low-skill IT manufacturing.

The estimations show that $(a)$ when offshoring takes place in the highly developed sector of IT-Manufacturing industries the relative wages go up, and (b) likewise, when

\footnotetext{
${ }^{20}$ See footnote 2 in the Introduction.

${ }^{21}$ High-skill IT-Manufacturing is defined as the average of our industries of study leaving Industry machinery out; low-kill is simply defined as Industry machinery. I have worked with all possible combinations for these definitions but none produced the unambiguous and significant results shown on Table 8 (e.g. skill upgrading).
} 
offshoring occurs in the less developed sector the relative wages go up in the highly developed sector. Figure 8 shows both the trends of relative wages (8a) and average wages in each industry (8b), and reinforces the idea that skill upgrading has been taking place among the industries involved in our study, especially after the East Asian crisis (1997).

\section{Figure 8. Relative wages and skill upgrading.}
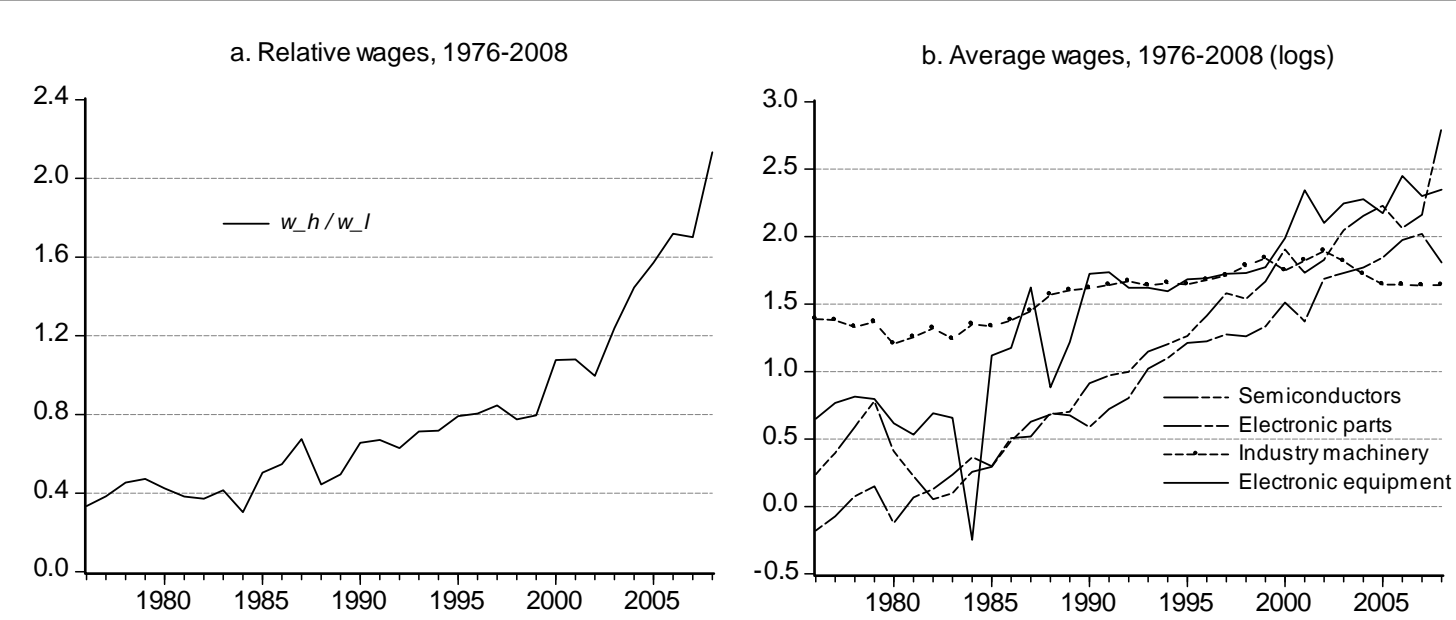

Another way to determine whether offshoring can be seen as a source of SBTC is by trying to measure its effects on the labor income share. ${ }^{22}$ If we define the labor share (LS) as the share of wages in the (gross) ${ }^{23}$ value added at factor prices, then it is possible for us to rearrange equations (1) and (4) above to track down its path over the recent years. For instance, when the LS goes down due to offshoring then resources are being reallocated from labor to capital-intensive activities (e.g. SBTC). To see this we will focus on the industry where, not surprisingly, the LS has fallen the most in recent times, the one we labeled Industry machinery - also the 'low-skill' IT-Manufacturing industry as we defined it in the previous exercise.

Following the notation in (1)-(4) the LS can be expressed as

$$
L S_{t}=w_{t}-\left(y_{t}-n_{t}\right)
$$

We need now to assume certain behavior of the wages so as to make them endogenous. For this we propose a simple relationship:

$$
w_{t}=\alpha_{3}+\gamma_{3} w_{t-1}+\nu \theta_{t}+\lambda_{3} O s_{t}+\varepsilon_{3}
$$

\footnotetext{
${ }^{22}$ As far as I know this line of research has not yet been developed in the literature.

${ }^{23}$ This word here makes a great deal of a difference in the case of Japan since depreciation has been really important, and not taking account of it (net value added) might well lead to exaggerating the real extent of the LS (on this see Wakita, 2006).
} 
where real wages depend on their past values, productivity, and the offshoring intensity index (as a measure of labor market conditions), and the coefficients comply with $0<$ $\gamma_{3}<1$ (dynamic stability), $\epsilon_{w-\theta}^{L R}=1$ (the long-run elasticity of wages to productivity being equal to 1$),{ }^{24}$ and $\lambda_{3}<0$ (due to international competition).

Endogenizing (9) in the system (1)-(4) allows us to track the changes in (8) by the same dynamic accounting exercise as before. Table 9 presents the estimation of the now 3-equation system for Industry machinery alone. Notice that the coefficients are not much different from those obtained before (Table 3c), and the offshoring coefficient in the output equation is now marginally significant.

Table 9: Endogenous wages, Industry machinery.

\begin{tabular}{|c|c|c|c|c|c|c|c|c|}
\hline \multicolumn{9}{|c|}{ 3-Eq. system (1976-2008), 3SLS } \\
\hline \multicolumn{3}{|c|}{ Dependent variable: $n_{t}$} & \multicolumn{3}{|c|}{ Dependent variable: $y_{t}$} & \multicolumn{3}{|c|}{ Dependent variable: $w_{t}$} \\
\hline \multicolumn{3}{|c|}{ coefficient } & \multicolumn{3}{|c|}{ coefficient } & \multicolumn{3}{|c|}{ coefficient } \\
\hline cnt. & 5.46 & {$[0.000]$} & cnt. & -7.43 & {$[0.005]$} & cnt. & -0.05 & {$[0.161]$} \\
\hline$n_{t-1}$ & 0.17 & {$[0.061]$} & $y_{t-1}$ & 0.31 & {$[0.106]$} & $w_{t-1}$ & 0.72 & {$[0.000]$} \\
\hline$w_{t}$ & -0.26 & {$[0.000]$} & $n_{t}$ & 1.12 & {$[0.000]$} & $\theta_{t}$ & 0.28 & {$[\dagger]$} \\
\hline$y_{t}$ & 0.39 & {$[0.000]$} & $k_{t}$ & 0.20 & {$[0.060]$} & $o s_{t}^{*}$ & -1.76 & {$[0.178]$} \\
\hline$o s_{t}$ & -3.68 & {$[0.000]$} & $o s_{t}^{*}$ & 4.07 & {$[0.163]$} & & & \\
\hline $\bar{r}^{2}$ & & 0.944 & & & 0.935 & & & 0.924 \\
\hline$S$ & & {$[0.348]$} & & & {$[0.685]$} & & & {$[0.335]$} \\
\hline
\end{tabular}

Note: p-values in brackets; $\bar{r}^{2}$ the adjusted r-squared; $S$ the p-value for the Sargan test;

${ }^{*}$ offshoring coefficient marginally significant; ${ }^{\dagger}$ restricted coefficient as to $\epsilon_{w-\theta}^{L R}=1$.

Figure 9 shows the results of the dynamic simulation for Industry machinery with endogenous wages. Figure 9a presents the fitted values and highlights the major drop in the LS in recent years $(2002-2008),{ }^{25}$ while Figure 9b displays the contribution of offshoring to the change in the LS during this period. Note that this is no small contribution, for the LS would have fallen less than it did had offshoring remained fixed at its 2002 level. Instead, the LS dropped almost 20 p.p. (from 87.6 to 67.7) and not 12 p.p. (from 87.6 to 75.9 ).

\footnotetext{
${ }^{24}$ I fail to reject this restriction for the wage equation so the coefficients there are restricted accordingly.

${ }^{25}$ Notice that the LS was not constant throughout the period, something which is consistent with non-constant returns to scale.
} 
Figure 9. The LS and offshoring, Industry machinery.

a. LS (\%), actual and fitted values

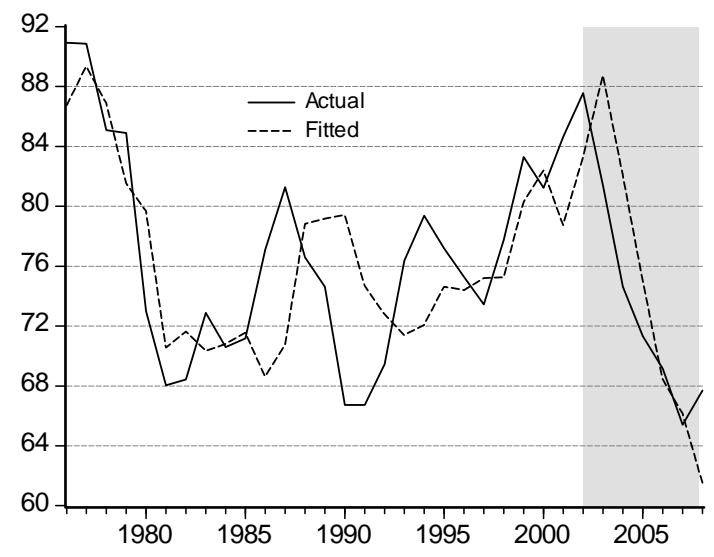

b. LS (\%) and offshoring contribution

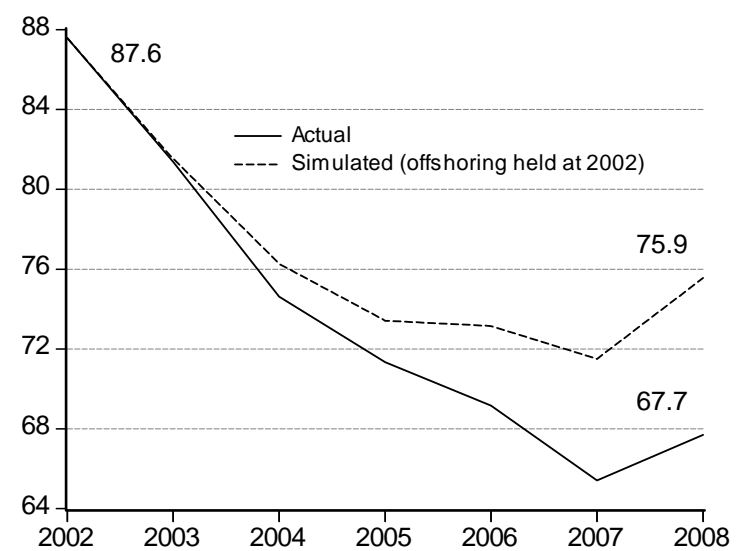

\section{$5 \quad$ Final remarks}

The subject of offshoring and productivity is still on its early days when compared to studies dealing with the more direct and not so friendly employment effects. As we have seen, productivity improvements can be achieved in some firms riding on the offshoring wave. Here we have focused on a small group of highly productive IT-Manufacturing industries in Japan during the long-lived (and still going) slump.

We have uncovered significant positive effects on the growth rate of labor productivity in the Semiconductors industry that are of the order of 3.81 average p.p. during 1997-2008 (or 0.38 per 1 p.p. of increase in the offshoring index). In addition, we have obtained positive and large, yet marginally significant effects, for the Electronic parts industry (8.87 average p.p. and 2.86 per 1 p.p. of increase in offshoring). Finally, the effects in the Electronic equipment industry were statistically not significant and those in Industry machinery were non-existent. Despite the lack of uniformity in the results, our analysis points to the importance of offshoring strategies for some firms, precisely on a time where they most need it, not only because of the slump, but also because of the increased competition of neighboring countries.

We have also produced some evidence on the existence of skill-biased technological change among these industries. First, we have found that relative wages tend to move with offshoring while favoring those industries with higher-skill labor. And second, for the relatively low-skill industry, we have estimated an important contribution of offshoring to the significant drop in the labor share. These results indicate that offshoring might be at the root of the big changes taking place both in Japan and in other developed economies in recent years. 


\section{References}

Agnese, P., 2012, Employment effects of offshoring across sectors and occupations in Japan, Asian Economic Journal, 26 (4), 289-311.

Amiti, M. and S-J. Wei, 2009, Service offshoring and productivity: Evidence from the US, The World Economy, 32, 203-220.

Berman, E., J. Bound, and Z. Griliches, 1994, Changes in the demand for skilled labor within U.S. manufacturing: Evidence from the Annual Survey of Manufacturers, The Quarterly Journal Economics, 109 (2), 367-397.

Caballero, R., T. Hoshi, and A. Kashyap, 2008, Zombie lending and depressed restructuring in Japan, American Economic Review, 98 (5), 1943-77.

Feenstra, R. and G. Hanson, 1996, Globalization, outsourcing, and wage inequality, American Economic Review, 86 (2), 240-245.

Forrester, 2007, Japan's offshore evolution: Baby steps toward China and India, by J. Browne and J. McCarthy.

Fukao, K. and H. Kwon, 2006, Why did Japan's TFP growth slow down in the Lost Decade? An empirical analysis based on firm-level data of manufacturing firms, Japanese Economic Review, 57 (2), 195-228.

Fukao, K. and S. Arai, 2013, Offshoring bias in Japan's manufacturing sector, RIETI Discussion Paper 13-E-002.

Geishecker, I. and H. Görg, 2005, Do unskilled workers always lose from fragmentation?, North American Journal of Economics and Finance, 16 (1), 81-92.

Girma, S. and H. Görg, 2004, Outsourcing, foreign Ownership, and productivity: Evidence from UK establishment-level data, Review of International Economics, 12 (5), 817-832.

Hayashi, F. and E. Prescott, 2002, The 1990s in Japan: A lost decade, Review of Economic Dynamics, 5, 206-235.

Head, K. and J. Ries, 2002, Offshore production and skill upgrading by Japanese manufacturing firms, Journal of International Economics, 58 (1), 81-105.

Hijzen, A., H. Görg, and R. Hine, 2005, International outsourcing and the skill structure of labour demand in the United Kingdom, The Economic Journal, 115, 860-878.

Hijzen, A., I. Tomohiko, and Y. Todo, 2010, Does Offshoring Pay? Firm-Level Evidence from Japan, Economic Inquiry, 48 (4), 880-895.

iSuppli Corporation supplied rankings, 2011.

Ito, K. and K. Tanaka, Does material and service offshoring improve domestic productivity? Evidence from Japanese manufacturing industries, RIETI Discussion Paper 10-E-010.

Johansen, S., 1988, Statistical analysis of cointegrating vectors, Journal of Economic Dynamics and Control, 12, 231-254.

Johansen, S., 1992, Determination of cointegration rank in the presence of a linear trend, Oxford Bulletin of Economics and Statistics, 54 (3), 383-97.

Krugman, P., 1998, It's back: Japan's slump and the return of the liquidity trap, Brooking Papers on Economic Activity, 2, 137-187.

OECD (2010), OECD Information Technology Outlook 2010, OECD Publishing. http: //dx.doi.org/10.1787/it_outlook-2010-en

Pantula, S., 1989, Testing for unit roots in time series data, Econometric Theory, 5 (2), 256-71.

Pesaran, M., 1997, The role of economic theory in modelling the long-run, The Economic Journal, 107 (440), 178-191. 
Pesaran, M. and Y. Shin, 1999, An autoregressive distributed-lag modelling approach to cointegration analysis, 371-413, in Strom, S. (ed), Econometrics and Economic Theory in the Twentieth Century: The Ragnar Frisch Centennial Symposium, Cambridge University Press, Cambridge.

Pesaran, M., Y. Shin, and R.J. Smith, 2001, Bounds testing approaches to the analysis of level relationships, Journal of Applied Econometrics, 16 (3), 289-326.

RIETI, Hitotsubashi University, and ESRI, Japan, Japan Industrial Productivity Database, 2011.

Tsai, C.-J., 2010, HRM in SMEs: homogeneity or heterogeneity? A study of Taiwanese high-tech firms, The International Journal of Human Resource Management, 21 (10), 16891711.

Wakasugi, R., 1988, Research and development and innovations in high technology industry: The Case of the semiconductor industry, The Japanese Economy, 17 (1), 3-35.

Wakita, S., 2006, S., 2006, The Lost Decade in the Japanese Labor Market: Labor's share and Okun's Law, Public Policy Review, 2 (1), 77-96.

Wall Street Journal (April 11, 2011), Even Japan Inc. looks offshore, by C. Dawson.

Yamada, B., 1990, Internationalization strategies of Japanese electronics companies: implications for Asian newly industrializing economies (NIEs), Working Paper No. 28 (Formerly Technical Paper No. 28) OECD Development Centre. 


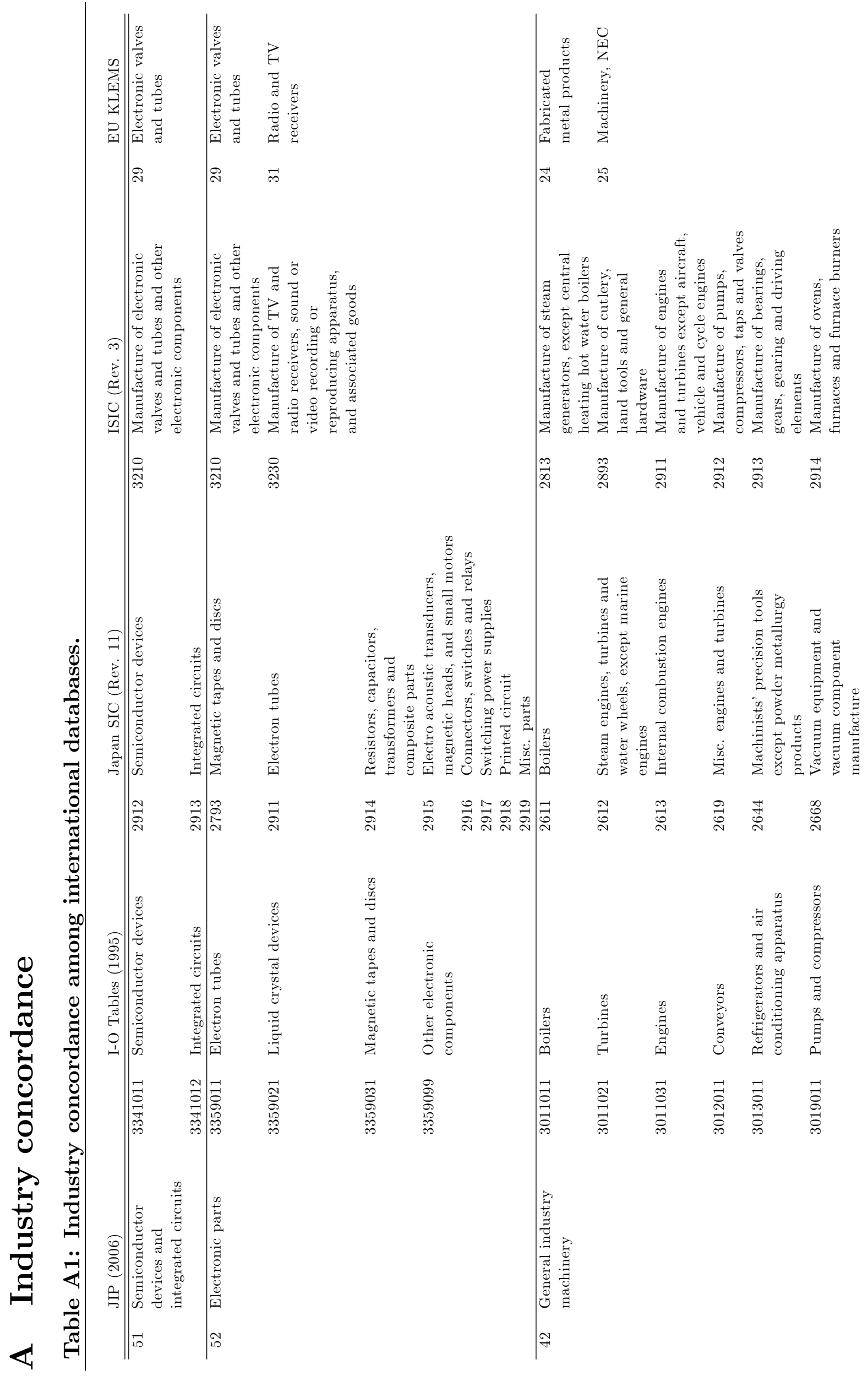




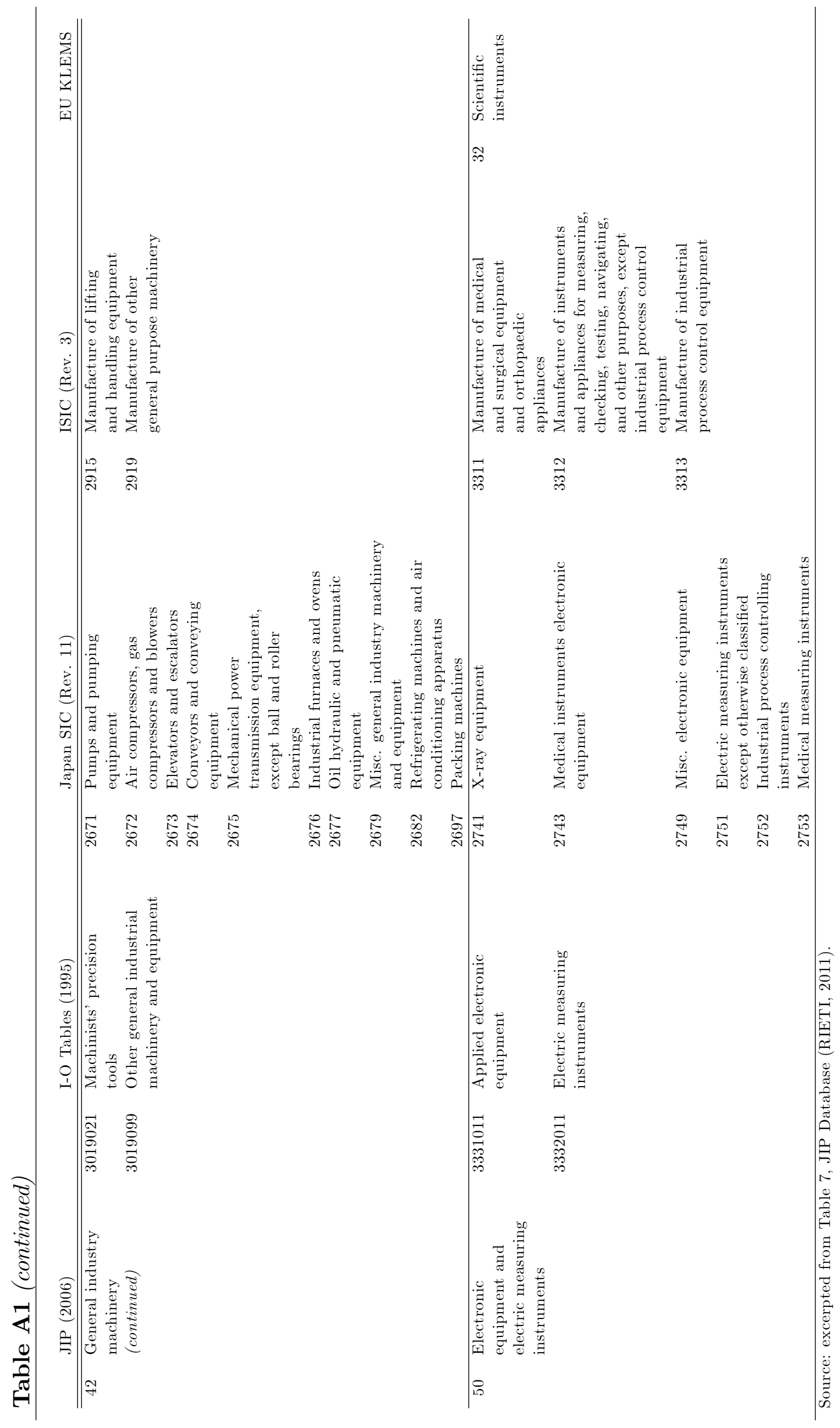




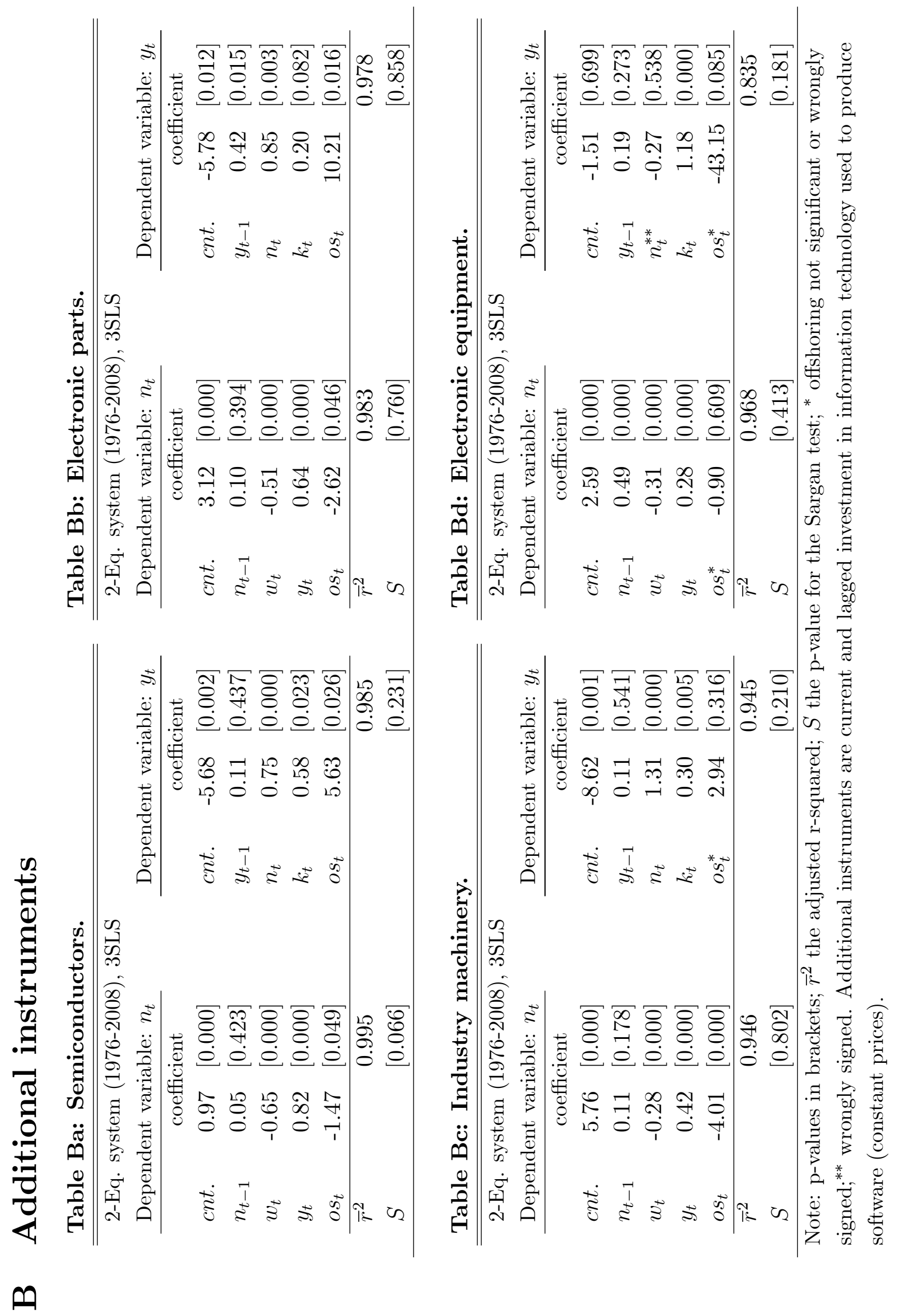

